\title{
Doubling Farmers Income in Horticultural Crops in Context of Post COVID-19 Era
}

\author{
Karishma Borah ${ }^{\text {* }}$, Himadri Shekhar Datta ${ }^{2}$, \\ Ranjit Kumar Saud ${ }^{3}$ and Sarat Sekhar Bora ${ }^{4}$ \\ ${ }^{1}$ Department of Horticulture, ${ }^{2}$ College of Horticulture, ${ }^{3}$ Director of Extension Education \\ (P\&I), ${ }^{4}$ SMS (Agro-meteorology), KVK, Udalguri, Assam Agricultural University, Jorhat- \\ 785013, Assam, India \\ *Corresponding author
}

\section{A B S T R A C T}

\section{Keywords}

Doubling farmers income, Horticultural crops

Article Info

Accepted:

26 September 2020 Available Online: 10 October 2020
Horticulture contributes to more than a third of the agricultural GDP of the country, though it occupies less than a fifth of the cultivated area. This stems from the fact that there is very high demand and a continued growth in consumption of fresh produce like fruits and vegetables. Floriculture is another growing subsector of Horticulture. Therefore, improving the income of the rural populace engaged in horticultural cultivation is a necessity in order to improve the economy of India. Doubling Farmers Income has been a topic of discussion for quite some time. Farmers who play a vital role in the Indian economy are mostly not aware of this Central Government strategy of doubling farmer's income by the financial year 2022-23. A huge amount of sum of the financial budget of the Central government is given for the upliftment of the agriculture and allied sector. However, the outbreak of the recent pandemic due to spread of Covid-19 virus had affected the horticultural farmers to a great extent. Most of the produce being perishable were being wasted on a large scale, owing to the lockdown announced by the government. Government has taken certain initiatives in order to compensate the farmers for their loss. In such a pandemic situation, a huge gap has been created, due to which doubling the farmers' income in horticultural crops by 2022 has become quite challenging, though it is an utmost necessity, in order to improve the economy of the country.

\section{Introduction}

Horticulture, a sub-sector of the larger agricultural sector, comprises a wide array of cultivation systems ranging from the seasonal to the annual, to the perennial. Broadly, the horticultural sector covers six categories, namely pomology (fruits), olericulture (vegetables), floriculture (flowers), plantation crops, spices, aromatics and herbal medicines. India has been endowed with a wide diversity of agro-climatic zones and remarkable soil structures, which allows production of variety of horticultural crops such as fruits, vegetables, flowers, spices, plantation crops, root and tuber crops, and medicinal and aromatic crops. Agriculture and allied sectors contributes to about $18 \%$ of the India's gross 
domestic product (GDP) and a large proportion of this contribution comes from the horticulture sub-sector. On account of their higher monetisable potential relative to field crops like cereals, pulses and oilseeds, horticulture sector is considered as a high value segment. The high value percolates from the higher demand from consumers, and from greater awareness of wholesome nutritional benefits from fresh whole food that horticulture offers. Horticultural crops play a unique role in India's economy by improving the income of the rural populace and provide enormous scope to small and marginal farmers with higher return per unit of land than any other staple crops. They also play an important role in overcoming vitamin and micronutrient deficiencies. Thus, horticulture is emerging as the main growth engine of Indian agriculture. Since, cultivation of horticultural crops is labour intensive; it generates employment opportunities for the rural population. Horticulture also uses hightech tools and practices and tends to attract rural youth, who generally display a proclivity for technology, as farmers and technology providers. As a result of research, education, technology and policy initiatives, horticulture in India has become a viable option for the small and marginal farmers. This sector has also stared attracting entrepreneurs for commercial ventures in a big way facilitated by technology driven scientific support.

Doubling Farmers' Income by 2022 has been a topic of discussion since last few years. In 2016, the Government of India constituted an expert committee headed by Ashok Dalwai to look into the entire agriculture sector of the country and suggest ways and means to improve it so that farmers' income can be doubled by 2022. Doubling Farmers' Income by 2022 is the most important discourse before the government, policymakers, academicians, researchers, politicians, farmers, and critics. Prime Minister 7-point plan i.e. "per drop, more crop"; quality seed and soil health card; warehousing and cold chain; value addition and food processing, farm market and e-NAM, new crop insurance scheme, and problems of small and marginal categories of farmers. However, due to the outbreak of the Covid-19 virus, more than 200 countries of the entire globe have been affected and India is also not left behind. Due to the severity in the spread of the virus, government had to declare lockdown in the entire country, due to which the economy and the trade of the country were worst affected. Moreover, the food security was also severely interrupted in such a pandemic situation. Unemployment has also become a major problem, due to which many migrant workers had to move back to their respective states. In such a situation, agriculture can play a vital role in order to solve the economic crisis caused due to lockdown. This is because, following the total lockdown situation, government had given some kind of relaxations to the farmers and tea garden labourers, in order to carry out their farm operations.

\section{Doubling Farmers’ Income (DFI)}

During the last four years, doubling farmers' income by 2022 has been the main theme of Agricultural sector. An annual growth rate of about 10.4 percent is required from 2019-20 to 2022-23 in order to achieve the ambitious goal of doubling the income of the farmers.

\section{What to double?}

The focus is to increase not only the farm income, the output or the income of the sector or the value added or GDP of agricultural sector, but the overall income of the farmers, i.e. Real Income and not the Nominal Income. Nominal Income (NI) is the income expressed in terms of money, and measured in current currency of the country (rupee, dollar, etc.). 
Real Income (RI) is the income of the individuals or the nations after adjusting for inflation.

$$
\mathrm{RI}=\mathrm{NI}-\text { Inflation }
$$

\section{Importance of Doubling Farmers' Income}

For overall development of the Agricultural sector

Farmers will have access to better farm machineries, advanced technologies and quality planting material

Both the quantity and quality of food can be achieved

Lead to the growth of the Indian economy

Agrarian distress and sharp increase in number of farmers' suicides will be reduced.

Action plan for doubling the farmer's income

Time period - up to 2022

Annual growth rate of $10.4 \%$ required

What is to be doubled:

Income of farmers

Not farm incomes only

Challenges faced in doubling farmers' income

There are certain challenges which need to be addressed and solved accordingly, while trying to achieve the ambitious goal of doubling the farmers' income, which are:

High cost \& less availability of quality planting material

Unavailability of quality planting material at the appropriate time and at the appropriate site, and even though it is available, then it is at a very high cost.
Lack of short duration high yielding varieties

Due to lack of short duration High Yielding Varieties (HYV), farmers often have to go for monocropping, even though they are willing to cultivate more than one crop in a year.

\section{High cost of production}

Due to lack of appropriate farm machineries and unavailability of advanced technologies, farmers have to bear with high cost of production, due to which the annual net return is relatively low.

\section{Lack of skilled labours}

There is lack of skilled labours in order to carry out the farm operations, as most of the youths are deviated towards working in cities.

\section{Low storage and processing facilities}

There is a huge shortage of post harvest infrastructures, such as cold storage unit, hermetic storage, warehouses, ripening chambers, besides lack of proper processing and transportation facilities. As a result, the farm produce are being wasted in the grassroot level itself, due to improper preservation facilities.

Market fluctuation in cropping and off season

Due to price fluctuation in the cropping and off-season, the farmers are unable to obtain better price realization out of their total produce

Imbalance \& more use of chemical fertilizer and pesticide

Extensive use of chemical fertilizers and pesticides by the farmers, without following 
any appropriate dose has led to the imbalance of the nutrient availability in the field. As a result, the soil fertility is reduced after few years of cultivation.

\section{Productivity of crops is low in comparison to national level}

While comparing the overall productivity of the crops in the national level, it is estimated that the productivity of the particular crops in the farmers' level is relatively low. This may be due to various factors, such as land is not being properly utilized, as also unavailability of high yielding cultivars, etc.

\section{Lack of marketing facility}

There is an unavailability of proper marketing channels for the sale of the farm produce by the farmers, due to which farmers are unable to get the right value out of their hard work.

\section{Prime Minister's Seven Point Strategy for Doubling Farmers' Income by 2022}

\section{Irrigation}

Large budget and integrated policies are being taken by Government, with the aim to achieve "per drop, more crop". To this effect, the Pradhan Mantri Krishi Sinchai Yojana (PMKSY) was implemented to ensure access to some means of protective irrigation to all agricultural farms in the country, thus bringing much desired rural prosperity.

\section{Soil health card}

The flagship programme of Soil Health Card (SHC) of the Government of India was implemented with the objective in order to issue soil card to the farmers to carry out crop-wise recommendation of nutrients and fertilisers. SHC is a printed report containing the status of soil with respect to 12 parameters. This scheme helps the farmers to grow quality planting material, based on the nutrient availability in the field.

\section{Warehouse}

It is estimated that around 40 per cent of the horticultural harvest under post harvest loss, due to unavailability of proper post-harvest infrastructures. So, large investments is to be done by the government in agricultural infrastructures, such as warehousing, cold chain storage, hermetic storage, refrigerated storage, in order to prevent post-harvest loss.

\section{Value addition}

Farm crops especially the horticultural crops have the potential to obtain extra income by processing, which results in value addition of the crops. Various kind of products, such as, pickles, jam, jelly, ketchups, bouquets, wreaths, garlands, etc. have a lot of demand in the market.

\section{National farm market}

The National Farm Market in the form of electronic National Agricultural Market (eNAM) is being linked to 585 Agricultural Produce Marketing Committee (APMC) mandis. This online trading portal aims to connect the farmers directly to the traders and exporters, so that they obtain a fair financial transaction. Small Farmers Agribusiness Consortium (SFAC) is the leading agency involved in the implementation of e-NAM.

\section{Crop insurance}

Insurance schemes, such as Pradhan Mantri Fasal Bima Yojana (PMFBY) was implemented with the aim of supporting sustainable production in agriculture sector. This scheme provides financial support to the farmers suffering from loss /damage arising 
out of unforeseen events. It also encourages the farmers to adopt innovative and modern agricultural practices. This scheme ensures constant flow of credit and stabilizes the income of the farmers.

\section{Agri allied activities}

Now-a-days, integrated farming system has come up as a productive model, which helps the farmers to not only earn additional income, but also to utilize the land properly. The government is encouraging the farmers in order to adopt such models (Table 1).

\section{Imposition of lockdown}

The COVID-19 pandemic in India is part of the worldwide pandemic of coronavirus disease 2019 (COVID-19) caused by severe acute respiratory syndrome coronavirus 2 (SARS-CoV-2). The first case of COVID19 in India, which originated from China, was reported on 30 January 2020. India currently has the largest number of confirmed cases in Asia, and has the third highest number of confirmed cases in the world after the United States and Brazil. Due to the severity in the spread of COVID-19, Government of India had to declare a 21 days total lockdown across the country, followed by phase wise lockdown in the country considering the hotspot of spread of the virus.

\section{Impact of lockdown on agriculture / horticulture sector}

Labour availability: Availability of labour for carrying out various farm operations were severely affected, as most of the migrant workers left to their respective states on account of unemployment, due to lockdown.

Harvest of Rabi crops coincide with the lockdown

Inability of the farmers to access market, due to issues in transportation and operation of markets

Loss of perishable items: The perishable produce, particularly the horticultural crops were wasted on a large scale, owing to the closure of market and transportation.

Due to rise in labour charges, commercial crops have become non remunerative.

More than about two third of the total income underwent loss during the period of lockdown.

As per the initial report, GDP growth is likely to achieve negative growth rate of -5 per cent.

Horticultural crop growers were highly affected, due to perishability of the produce and lack of appropriate preservation facilities.

Due to closure of temple and restrictions in marriage ceremonies, flower growers were severely affected

Due to lack of proper Post harvest management infrastructures, huge loss of harvest was encountered due to closure of markets.

Though increased production, farmers unable to obtain maximum profit due to:

Lack of proper market linkage

Lack of storage facilities / cold chain infrastructure

Huge post-harvest loss

Blockage of inter-district and inter-state transport

Lack of adequate value addition and processing

\section{Initiatives undertaken by government during lockdown}

Amendment of the Essential Commodities Act was done for better price realization by the farmers.

Promotion of e-trading of agricultural produce was done as the markets / mandis were 
closed due to the lockdown. The e-NAM linked to 585 APMC mandis enabled the farmers to sell their produce by connecting them directly to the traders and exporters. This online trading portal also helped the farmers to reduce human contact and mitigate the spread of COVID-19.

Operation Green was implemented, in order to prevent the distress sale and ensure availability of fresh produce like fruits and vegetables throughout the country, all round the year. The ambit of the Operation green was extended from Tomatoes, Onion and Potatoes

Imposing of stockholding limits on cereals, pulses, edible oil and other food stuffs, which have been saved under extraordinary conditions of war, famine or annual retail price increase above 50 per cent. Such stock controls are however not applicable to processors and exporters.

Sale and purchase of farm produce was permitted outside the physical boundaries of regulated wholesale markets. It will provide freedom to the farmers to sell their produce directly to processors, traders, within or outside the state and also through electronic trading platforms.

Honourable Prime Minister of India, Shri Narendra Modi sanctioned Rs. 20 lakh crores for the implementation of the 'Atma Nirbhar Project', with a tag line that reads 'tough times require tough decision'. This project was implemented in order to develop a self-reliant nation with a package sum amounting to 10 per cent of the country's GDP, which would rest on five pillars of Economy, Infrastructure, System, Demography and Demand.

Under the Pradan Mantri Kisan Samman Niddhi (PM-KISAN) Scheme, Government transferred around Rs.
$19,100.77$ crores to 9.65 crores farmers during the period of lockdown.

Strategies / mechanisms that can be adopted for Doubling Farmers' Income by 2022 post COVID era

\section{By increasing productivity of crops}

Timely supply of good quality planting material

Timely availability of good quality inputs

Use of short duration high yielding varieties

Promotion of Farm Mechanization

Application of Integrated Nutrient Management

Application of Integrated Pest Management

By increasing irrigation facilities \& enhancing water-use efficiency

\section{By increasing cropping intensity}

According to the land capability, irrigation and other facilities available, a farm plan should be prepared for Kharif and Rabi for a minimum of 3 years e.g.

Sequential cropping: Okra-potato-chilli

Triple cropping: Cucumber (June-Sept)Cauliflower/Cabbage (October-January)

- Watermelon (February-May)

Quadruple cropping: Okra (July-Sept) - Early Cauliflower (Sept-Dec) - French bean (Dec-March) - Round Melon (April July)

Relay cropping: Planting of chilli in sweet corn field \& Sowing of cucurbits in potato field

Inter cropping: Rows of marigold in between gladiolus as a main crop

Short duration hybrid/HYV seeds to be used

Use of rice fallow land, waste / unutilised upland, abandoned / sick tea garden (Table 2). 
Creating marketing facilities for getting best recovery price of produce

Implementation of e-NAM

Formation of Farmer Producer Organisation / Farmers' Co-operative Societies

Create more marketing channels

Market-oriented variety wise cultivation

Assured price scheme

Effective procurement strategies to procure on MSP

Trading policies should be farmer-oriented, not trader oriented

Price-deficit financing scheme

Diversification of cropping system with high value crops

Cash crops- Betel leaf, Black pepper, Flowers, Vegetables, Fruits, Bamboo

Spices - Turmeric, Ginger, Coriander, Garlic, Onion, Ajwain and Fennel

Medicinal and Aromatic plants - Aloe vera, Sarpagandha, Aswagandha, Periwinkle (Table 3)

\section{Mushroom Cultivation}

\section{Rearing of honey bee}

\section{Promotion of integrated farming system}

Synergistic blending of crops/horticulture, dairy, fishery, apiary and poultry to provide regular income.

Integrated farming system approach is not only a reliable way of obtaining fairly high productivity with considerable scope for resource recycling, but also concept of ecological soundness leading to sustainable agriculture.

Protected cultivation of vegetables and flowers with Micro irrigation

Availability of storage, processing, pack house, refrigerated van, ripening chamber, warehouses, cold chain \& marketing, etc.

Management of post-harvest losses for horticultural crops through value addition

By reducing cost of production

Subsidy on farm inputs

Provision of subsidy on HYV/ hybrid variety of seeds in light of market price

Inclusion of green manuring crops e.g. Dhaincha, Moong, Cowpea, Sunhemp etc.

Application of balance dose of fertilizer on the basis of soil health card

Provision of subsidy on diesel

Promotion of CHC by youth

Use of bio fertilizers e.g. Rhizobium, PSB, Azotobactor, Azolla, Blue green Algae, Mycorrhiza

Subsidy of transport

Use of Gobar / Bio gas

Promotion of zero tillage technology

Use of Organic fertilizers and Manures

Formulation of Land Leasing Act

Digitization of Land Records

Certificate of cultivation for tenant farmers

Provision for practicing kitchen gardening for Urban households and poor people

Implementation of Pradhan Mantri Fasal Bima Yojana (PMFBY)

Regular region wise weather forecasting must be made available to farmers

Agro forestry or silviculture must be incorporated in the farming system, depending on the availability of land

Construction of water harvesting structures

Risk Management to cope up with climate change, through Climate Smart Agriculture 
Table.1 Integrated farming models and economics per hectare (DFI VIII, Ministry of Agriculture \& FW, 2017)

\begin{tabular}{|l|c|c|c|c|}
\hline \multicolumn{1}{|c|}{ Component } & $\begin{array}{c}\text { Employment } \\
\text { generation (man } \\
\text { days) }\end{array}$ & $\begin{array}{c}\text { Total } \\
\text { expenditure } \\
\text { (Rs.) }\end{array}$ & $\begin{array}{c}\text { Net } \\
\text { Returns } \\
\text { (Rs.) }\end{array}$ & $\begin{array}{c}\text { B:C } \\
\text { ratio }\end{array}$ \\
\hline Multi-storeyed cropping & 87.2 & 3,831 & 9,089 & 3.37 \\
\hline Pomology & 18.4 & 900 & 1,466 & 2.63 \\
\hline Olericulture & 96.4 & 3,812 & 8,302 & 3.18 \\
\hline Floriculture & 4.0 & 125 & 100 & 1.80 \\
\hline Mushroom & 180.0 & 18,181 & 12,856 & 1.70 \\
\hline Apiary & 1.0 & 170 & 1,180 & 7.94 \\
\hline Biogas & 11.0 & 600 & 1,431 & 3.38 \\
\hline
\end{tabular}

Table.2 Performance of Horticulture-Based Farming Systems Models in Terms of Production and Economics (Panwar et al., 2019)

\begin{tabular}{|l|l|c|c|c|c|}
\hline \multicolumn{1}{|c|}{ Location } & \multicolumn{1}{|c|}{ IFS Model } & $\begin{array}{c}\text { Area } \\
\text { (ha) }\end{array}$ & $\begin{array}{c}\text { Production (Eq. Yield } \\
\text { of Base Crop of } \\
\text { Region) (t/year) }\end{array}$ & $\begin{array}{c}\text { Annual Net } \\
\text { Profit } \\
\text { (Lakh/year) }\end{array}$ & $\begin{array}{c}\text { Empower } \\
\text { (Man } \\
\text { days/year) }\end{array}$ \\
\hline $\begin{array}{l}\text { Andaman and } \\
\text { Nicobar Island }\end{array}$ & CBFS + Pig based IFS model & 1.0 & 36 (rice eq. Yield) & 2.23 & 198 \\
\hline Goa & Plantation + Pig + Poultry & 0.8 & 23 (rice eq. Yield) & 0.89 & 508 \\
\hline Kerala & Coconut Based IFS- model & 0.2 & 11 (rice eq. Yield) & 0.57 & 127 \\
\hline Rajasthan & Agri-horti based IFS-model & 2.0 & 15.1 (pearl millet eq. & 1.32 & 350 \\
\hline Rajasthan & Fruit trees + field crop + & 1.0 & 7.8 (cluster bean eq. & 0.97 & 225 \\
\hline Uttar Pradesh & Orchard based IFS model & 1.5 & 41 (rice eq. Yield) & 4.29 & 742 \\
\hline
\end{tabular}

Plate.1 Article published in The Hindu Business Line regarding 'Lockdown Impact: Farmers turn back on vegetable cultivation'

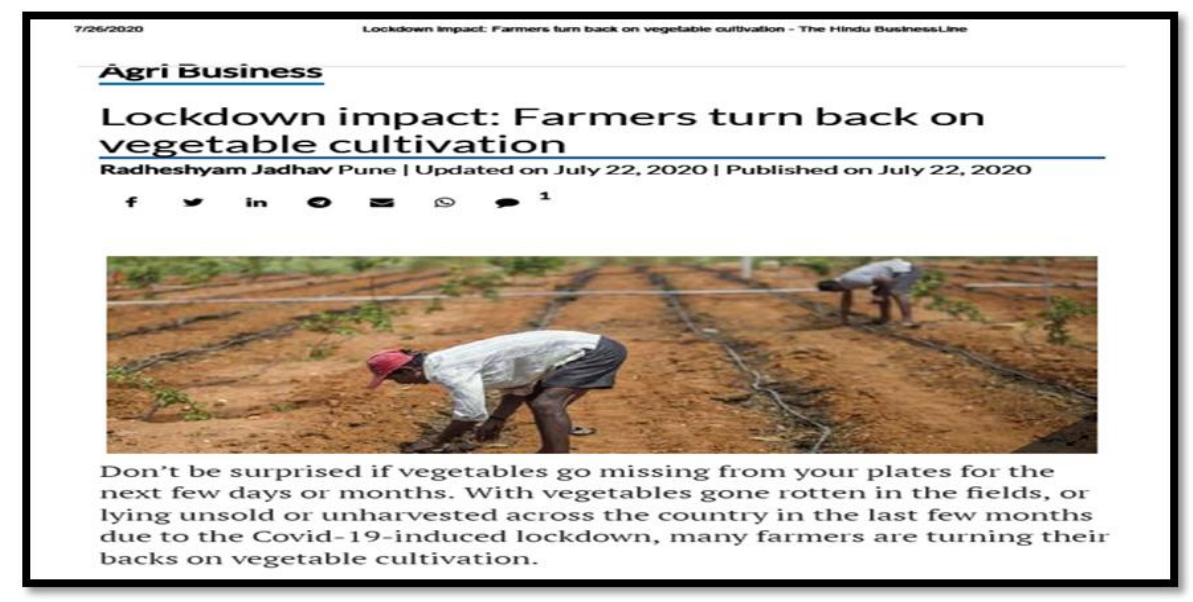


Table.3 Region Specific IFS models for partially irrigated arid condition in 2.0 ha through crop diversification (Bharadwaj and Vyas, 2015)

\begin{tabular}{|c|c|c|c|c|c|c|}
\hline Models & Major Component & $\begin{array}{c}\text { Cost of } \\
\text { Cultivation (Rs. } \\
\text { in lakhs) }\end{array}$ & $\begin{array}{l}\text { Gross } \\
\text { return } \\
\text { (Rs. in } \\
\text { lakhs) }\end{array}$ & $\begin{array}{l}\text { Net } \\
\text { return } \\
\text { (Rs. in } \\
\text { lakhs) }\end{array}$ & $\begin{array}{c}\text { B:C } \\
\text { Ratio }\end{array}$ & $\begin{array}{c}\text { Generate } \\
\text { employment } \\
\text { (Man Days) }\end{array}$ \\
\hline Model-1 & $\begin{array}{l}\text { Rabi- wheat, mustard, } \\
\text { barley, gram etc. } \\
\text { Kharif- Maize, bajra, } \\
\text { green gram, } \\
\text { cluster bean etc. }\end{array}$ & 0.60 & 1.82 & 1.22 & 2.03 & 480 \\
\hline Model-2 & $\begin{array}{l}\text { Fennel- } 0.5 \text { ha, Castor }-0.5 \\
\text { ha, Cotton- } 0.5 \text { ha, Other } \\
\text { crop- } 0.5 \text { ha }\end{array}$ & 0.78 & 2.85 & 2.06 & 2.64 & 780 \\
\hline Model-3 & $\begin{array}{l}\text { Rabi-Tomato, brinjal, } \\
\text { colecrop, pea etc. } \\
\text { Kharif- Okra, cucurbits } \\
\text { Zaid- Okra, chilli, } \\
\text { cucurbits }\end{array}$ & 1.68 & 6.80 & 4.12 & 3.04 & 1250 \\
\hline Model-4 & $\begin{array}{l}\text { Crop- } 0.6 \text { ha, Cash crop- } \\
0.7 \text { ha } \\
\text { Vegetable }-0.7 \text { ha }\end{array}$ & 1.02 & 2.85 & 2.91 & 2.86 & 850 \\
\hline Model-5 & $\begin{array}{l}\text { Crop- } 0.5 \text { ha, Cash crop- } \\
0.5 \text { ha } \\
\text { Vegetable }-0.5 \text { ha, Fruit } \\
\text { plants- } 0.5 \text { ha }\end{array}$ & 0.90 & 4.32 & 3.33 & 3.75 & 1170 \\
\hline Model-6 & $\begin{array}{l}\text { Crop- } 0.4 \text { ha, Cash crop- } \\
0.4 \text { ha } \\
\text { Vegetable }-0.4 \text { ha, Fruit } \\
\text { plants- } 0.4 \text { ha } \\
\text { Flower }-0.4 \text { ha }\end{array}$ & 1.05 & 5.07 & 4.01 & 3.80 & 1500 \\
\hline Model-7 & $\begin{array}{l}\text { Crop- } 0.4 \text { ha, Cash crop- } \\
0.4 \text { ha } \\
\text { Vegetable }-0.4 \text { ha, Fruit- } \\
0.4 \text { ha } \\
\text { Flower }-0.4 \text { ha with retail } \\
\text { marketing }\end{array}$ & 1.20 & 6.50 & 5.29 & 4.38 & 1800 \\
\hline
\end{tabular}

Table.4 Comparison of traditional and hi-tech horticulture (High density planting) for yield and nutrient management; Haldankar et. al. (2013); Reddy (2004)

\begin{tabular}{|c|c|c|c|c|c|}
\hline Spacing & $\begin{array}{c}\text { Plant } \\
\text { population } \mathrm{ha}^{-1}\end{array}$ & N $\left(\operatorname{kg~ha}^{-1}\right)$ & P $\left(\mathrm{kg} \mathrm{ha}^{-1}\right)$ & K $\left(\mathrm{kg} \mathrm{ha}^{-1}\right)$ & Yield $\left(\mathrm{t} \mathrm{ha}^{-1}\right)$ \\
\hline \multicolumn{6}{|l|}{ Mango } \\
\hline Regular $10 \mathrm{~m} \times 10 \mathrm{~m}$ & 100 & 150 & 50 & 100 & 5 \\
\hline HDP $5 \mathrm{~m} \times 5 \mathrm{~m}$ & 400 & 600 & 200 & 400 & 15 \\
\hline \multicolumn{6}{|l|}{ Guava } \\
\hline Regular $8 \mathrm{~m} \times 8 \mathrm{~m}$ & 156 & 93 & 46 & 46 & 15 \\
\hline HDP $6 \mathrm{~m} \times 2 \mathrm{~m}$ & 833 & 299 & 149 & 149 & 47 \\
\hline
\end{tabular}


Table.5 Income earned by farmers from different enterprises under Protected conditions (Choudhary, 2016)

\begin{tabular}{|l|c|c|c|}
\hline \multicolumn{1}{|c|}{ Particulars $(\mathbf{n = 5 6 )}$} & Unit size $\left.\mathbf{( m}^{\mathbf{2}}\right)$ & \multicolumn{2}{|c|}{ Net income (Rs/annum) } \\
\cline { 2 - 4 } & & \multicolumn{1}{|c|}{ Range } & Average \\
\hline $\begin{array}{l}\text { Flower cultivation } \\
\text { (carnation and roses) }\end{array}$ & 500 & $40,000-3,03,030$ & $1,64,040$ \\
\hline $\begin{array}{l}\text { Vegetable cultivation } \\
\text { (coloured capsicum, } \\
\text { tomato, cucumber) }\end{array}$ & 500 & $50,000-3,50,000$ & $1,17,763$ \\
\hline
\end{tabular}

Plate.2 Article published in The Telegraph Online on 'Give relief or will die: Farmers of Lower Assam'

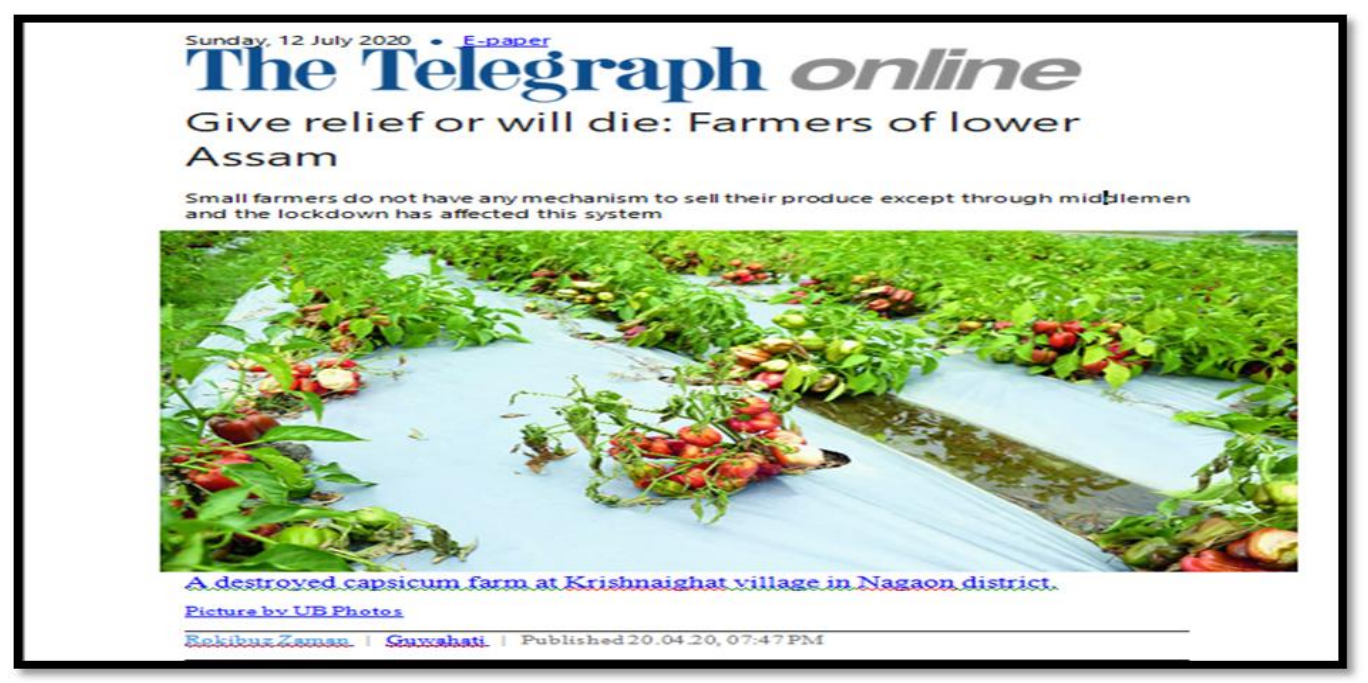

Plate.3 Article published in Inside NE We Deliver the Northeast on 'Covid-19 Lockdown Cripples Farming Economy of Assam ahead of Monsoons’

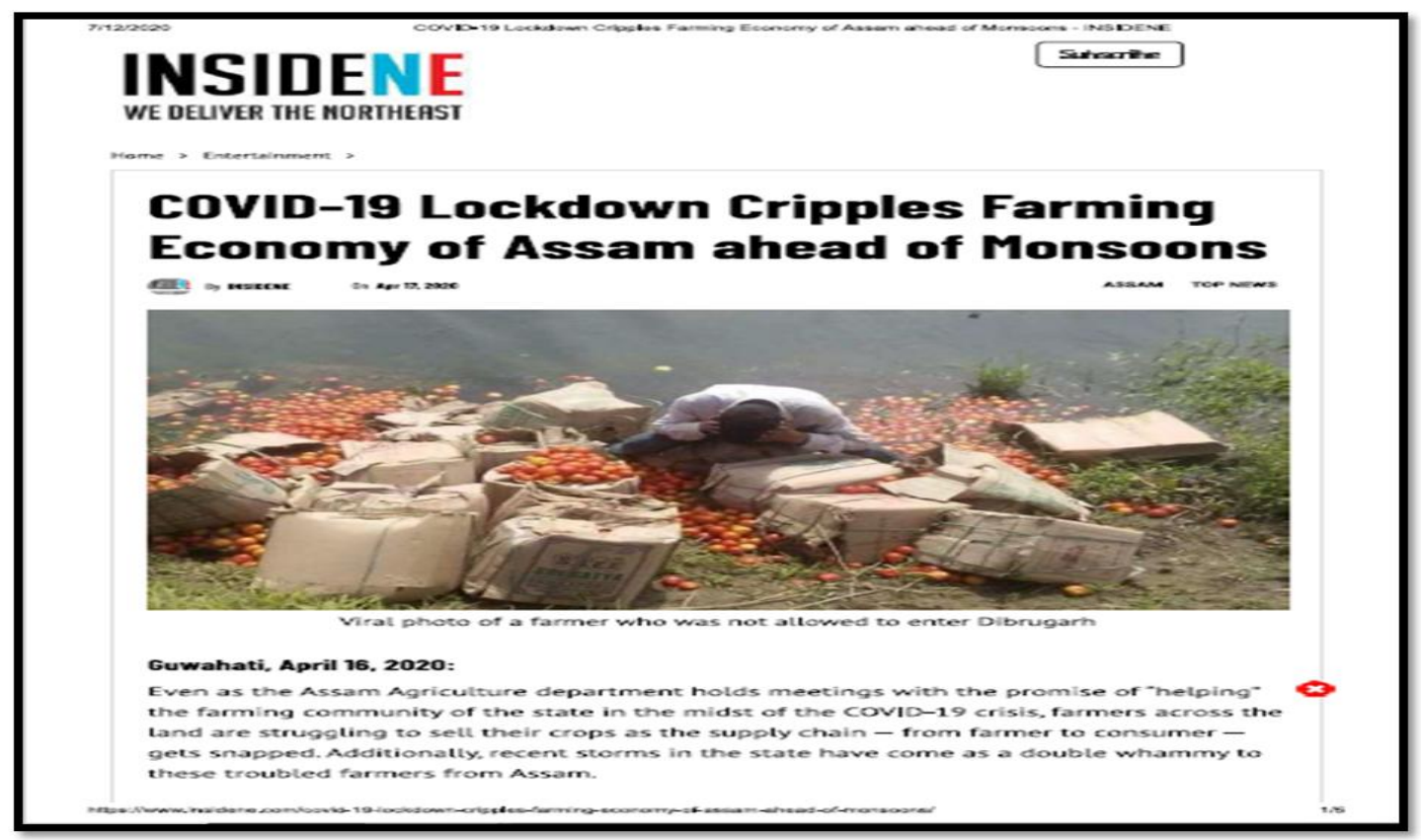




\section{Implementation of Hi-tech Horticulture for Doubling Farmers' Income}

Hi-tech horticulture is a technology which is modern, less environment-dependent and capital intensive but with a capacity to improve productivity and farmers' income.

Hi-tech technology refers to the precise production techniques for the efficient use of inputs at the appropriate time and quantity for maximization of yield and quality in different horticultural crops.

Powerful tool for Doubling Farmers Income It has the potential to improve productivity and quality of horticultural crops

There are different themes to carry forward the goals of hi-tech horticulture, which are the enumerated below:

\section{Climate-resilient production technology}

Adoption of climate-resilient production technology, including nursery development through hi-tech interventions

\section{Conservation of existing germplasm}

Conservation of existing germplasm and exploitation of underutilised plants and land use with development of new varieties / hybrids suited for hi-tech horticulture.

\section{High density planting}

High density planting with appropriate canopy management is to be done. Moreover, promotion of bee-keeping is done for better productivity and mutual benefits.

\section{Precision farming}

Precision farming oriented to targeted yield, crop and region specific nutrient management and irrigation resource conservation.

\section{Development of value added chain}

Development of a value added chain must be done, in order to reduce the post-harvest losses and value addition.

\section{Application of biotechnology and nanotechnology}

Application of biotechnology and nanotechnology is to be done for crop improvement and value addition.

Floriculture, a diverse sector of Horticulture for DFI

Floriculture is the culture of flowers and other ornamental foliage plants, trees, shrubs, palms, ferns, bamboos, cacti and succulents, besides landscape gardening.

Floriculture, the profession of production of ornamental plants and their products one considered as gardener's activity is now fast emerging as a major, important and commercial agri-venture in India.

Modules for doubling farmers' income in Floriculture:

Nursery Raising

Loose Flower Production

Cut Flower Production

Protected Cultivation

Open Field Cultivation

Flower Seed Production

Bonsai Production

Dry Flower Industry

Value Addition

Horti Tourism

Floriculture has a huge potential to provide our farmers their rightful fruits of labour and dedication. Present necessity of agricultural diversification through exploring such aspects of it can enhance and double the farmers' 
income, thereby uplifting their standards of living and giving them a secure future.

\section{Way forward}

Use of GIS / Spatial data service for accurate mapping of resources to prepare a solid annual data plan of activities in different horticultural crops.

Creation of platforms for production of seeds, planting materials and organic inputs in PPP mode

Cluster approach for growing of commercially important horticultural crops with promotion of bee-keeping utilizing waste lands

Development of organic clusters in niche horticultural crops under protected environment having drip cum fertigation system with sound marketing strategies

Mission mode programme for promotion of medicinal plants, spices and citrus crops in large cluster with appropriate PHM infrastructural facilities

Establishment of integrated collection, grading, packaging and small scale processing centres with availability of cold storage, refrigerated vans, etc

Development of horti based integrated farming system for small and marginal farmers for raising their monthly income

Promotion of farm mechanization to reduce cost of production by introducing machineries for different horticultural operations in each cluster

Promotion of roop top gardening and periurban horticulture in cities

Development of custom hiring centres in villages by youth with availability of farm machineries like tractors, power tillers, etc.

Establishment of Horti-incubation hub having the facilities for sales counter of seeds, planting materials, farm machineries, agro-chemicals including organic input,
Machinery repairing centre, Plant clinics for testing and plant protection, Bank finance, DPR preparation, Farmers' Club and Advisory services.

\section{Suggestions}

Rate of increase in sources underlying growth need to be accelerated by 33 per cent

Increased use of quality seed by 12.8 per cent, fertiliser by 4.4 per cent and power supply by 7.6 per cent required every year

Area under irrigation expanded by $1.78 \mathrm{~m}$ ha every year

Area under double cropping increased by 1.85 $m$ ha every year

Area under fruits, vegetables and flowers to be increased by 5 per cent each year

In conclusion the current pandemic situation, doubling farmers' income in horticultural crops by 2022 is quite challenging, but is a necessity. Three prolonged strategy required on:

\section{Development initiatives}

Initiatives are to be taken in order to bring overall development of the farmers, thus resulting in their enhanced income. Farmers must be given appropriate package and practice of the horticultural crops, so that they can farm operations and apply various manures and fertilisers accurately.

\section{Technology advancement}

Farmers are to be provided enough subsidies to adopt various advanced technologies, such as hi-tech horticulture, floriculture, precision farming, etc. Moreover, farm mechanisations in the form of farm machineries like tractors, power tillers, etc. are to be provided to the farmers. 


\section{Policy reforms in horticulture}

Government of India as well as state must pay necessary attention to the horticultural farmers, so that they are not deprived from getting benefitted from different agricultural policies. A policy reform is required in horticultural sector in order to establish necessary post-harvest infrastructures, such as cold storage unit, hermetic storage, warehouses, ripening chambers, processing unit, refrigerated vans, etc.

\section{References}

Anon. (2017). Pradhan Mantri Krishi Sinchai Yojana. Available at: https://vikaspedia.in/agriculture/policies -and-schemes/crops-related/pradhanmantri-krishi-sinchai-yojana. Accessed $30^{\text {th }}$ July, 2020.

Anon. (2019). Policy Paper on doubling farmers income. Available at: https://vikaspedia.in/agriculture/policies -and-schemes/policy-paper-ondoubling-farmers-income. Accessed 28th July, 2020.

Anon. (2020). Covid-19 Lockdown Cripples Farming Economy of Assam ahead of Monsoons. InsideNE We Deliver the Northeast. Published on April $16^{\text {th }}$, 2020.

Anon. (2020). COVID-19 pandemic in India. Available at: https://en.wikipedia.org/wiki/COVID19_pandemic_in_India. Accessed $2^{\text {nd }}$ August, 2020.

Bharadwaj, R.L., Vyas, L. (2015). Development of Region Specific Horticulture based Integrated Farming System Models with Crop Diversification for Sustainable Livelihoods and Nutritional Security of Tribal of Sirohi District of Rajasthan: A Case Study. Advances in Social Research. 1(1): 17-29.
Bhattacharyya, T., Haldankar, P.M., Patil, V.K., Salvi, B.R., Haldavanekar, P.C., Pujari, K.H. and Dosani, A.A. 2017. Hitech Horticulture: Pros and Cons. Indian Journal of Fertilisers. 13 (12): 46-58.

Choudhary, A.K. (2016). Scaling-up of protected cultivation in Himachal Pradesh, India. Current Science. 111(2): 272-277.

Committee for Doubling Farmers' Income, Ministry of Agriculture \& Farmers' Welfare. (2017). Resource use efficiency or saving in cost of production. Report of the Committee for Doubling Farmers' Income. pp. 70-86.

Deka, B.C. Biswas, P.K. (2020). Horticulture - A Sunrise Sector in Northeast India. Prospects of Northeast Agriculture in post COVID 19 scenario. pp. 76-88.

Haldankar, P.M., Parulekar, Y.R., Haldavanekar, P.C., Pawar, C.D., Desai, V.S. and Pandey, V.S. (2013). Mango Production Technology. Dr. Balasaheb Sawant Konkan Krishi Vidyapeeth, Dapoli.

Jadhav, R. (2020). Lockdown Impact: Farmers turn back on vegetable cultivation. The Hindu Business Line. Published on July $22^{\text {nd }}, 2020$.

Panwar, A.S., Kashyap, P., Ravisankar, N., Prusty, A.K. and Shamim, M. (2019). Horticulture based Integrated Farming Systems: A Viable Options for doubling farmers income. Shaping the Future of Horticulture. Kruger Brentt Publishers. pp. 495-509.

Reddy, B.M.C. (2004). High density planting in horticultural crops. In Crop Improvement and Production Technology of Horticultural Crops. Volume 1. (K.L. Chadha, B.S. Ahluwalia, K.V. Prasad and S.K. Singh, Eds.), pp 295-319. The Horticulture Society of India, New Delhi.

Salaria, A.S., Salaria, B.S. (2014). A2Z Horticulture at a Glance - III 
Floriculture, Landscape Gardening, Medicinal and Aromatic Plants. INTELLECTS: Nurture to Excel Publishers. pp. 1-66.

Singh, R.R., Meena, L.K. and Singh, P. (2017). High Tech Nursery Management in Horticultural Crops: A Way for Enhancing Income.
International Journal of Current Microbiology and Applied Sciences. 6(6): 3162-3172.

Zaman, R. (2020). Give relief or will die: Farmers of Lower Assam. The Telegraph Online. Published on April $20^{\text {th }}, 2020$.

\section{How to cite this article:}

Karishma Borah, Himadri Shekhar Datta, Ranjit Kumar Saud and Sarat Sekhar Bora. 2020. Doubling Farmers Income in Horticultural Crops in Context of Post COVID-19 Era. Int.J.Curr.Microbiol.App.Sci. 9(10): 3148-3161. doi: https://doi.org/10.20546/ijcmas.2020.910.378 